\title{
Host Range and Cross Infectivity of the Genus Magnaporthe grisea
}

\author{
S. Shanmugapackiam ${ }^{1 *}$ and T. Raguchander ${ }^{2}$ \\ ${ }^{1}$ Department of Plant Pathology, ICAR - Krishi Vigyan Kendra, Vamban, Pudukkottai - 622 \\ 303, Tamil Nadu, India \\ ${ }^{2}$ Department of Plant Pathology, Tamil Nadu Agricultural University, Coimbatore - 641003 , \\ Tamil Nadu, India \\ *Corresponding author
}

\section{A B S T R A C T}

\section{Keywords \\ Blast, Finger millet, Minor millet, Rice, Weeds \\ Article Info \\ Accepted: \\ 22 July 2018 \\ Available Online: \\ 10 August 2018}

Blast (Magnaporthe grisea) is an economically important disease of finger millet in India. The cross infectivity of $M$. grisea isolates of leaf, neck and finger blast from finger millet can infect weed host viz., Pennisetum cenchroides, Pennisetum pureum and Cynodon dactylon but not the rice, foxtail millet and little millet. The vice versa pattern of cross infection were observed between the leaf, neck and finger blast pathogens. This shows that the weed management is more important in finger millet fields to manage the blast disease and growing of finger millet adjacent to weed host is dangerous for blast epidemics in finger millet since weed host viz., $P$. cenchroides, $P$. pureum and $C$. dactylon serves as the source of inoculums.

\section{Introduction}

Blast disease caused by Magnaporthe grisea is an economically important disease of finger millet which causes significant losses in yield. Various weed hosts growing near cultivated plants might serve as potential sources of inoculums for the disease and thus provide alternate means of survival for the fungus. Since collateral and alternate hosts are the most important sources of inoculums which are present throughout the year. Study of the host range has become an important aspect of the disease management. Finger millet blast caused by Magnaporthe grisea (Hebert) Barr. (anomorph Pyricularia grisea (Cooke) Sacc. is a heterothallic, filamentous fungus, one of the major destructive disease causing excessive damage to this crop from seedling to ear head forming stages.

The disease occurs during all growing seasons and on almost all finger millet varieties cultivated. $M$. grisea parasitizes over 50 grasses, including economically important crops like wheat, rice, barley and millet $(\mathrm{Ou}$, 1985). Yield loss due to blast can be as high as $50 \%$ when the disease occurs in epidemic proportions. The fungus appears to overwinter as mycelia in the infected living leaves or dead plant debris in the soil (Uddin, 2000). Thomas (1941) reported that the blast disease on finger millet caused by $M$. grisea fails to infect the rice and ginger but does infect the wheat, 
barley and oats. He also found that strains from rice and Panicum repens would infect only its own host and the strains from finger millet and Setaria italica were capable of infecting wounded leaves of each other but would not infect rice or $P$. repens. Todman et al., (1994) reported that Magnaporthe isolates from $E$. coracana failed to infect rice and vice versa. Similar results were reported by Viji et al., (2000) stated that ten isolates of M. grisea from rice did not infect the finger millet and vice versa under laboratory conditions. This research aimed at estimating the possibility of the genotype alteration in $P$. grisea $\mathrm{dc} 4$ isolated from Digitaria ciliaris, following cross infection to either rice cv. Kencana bali, Cisokan and IR64 or Panicum repens, Cynodon dactylon, Digitaria sp. and Ottochloa nodosa. Khadka et al., (2012) showed that the $M$. grisea isolates from rice were able to infect all the plant species viz., rice, finger millet, Panicum sp., E. indica and Setaria sp. while isolates from finger millet were only able to infect three plant species viz., E. coracana, Setaria sp. and E. indica.

\section{Materials and Methods}

\section{Collection and isolation of pathogen}

In major finger millets growing regions of Tamil Nadu and from the All India Coordinated Small Millet Improvement Project (AICSMIP) centers, the blast infected finger millet plant parts viz., leaf or neck or finger blast infected samples were taken at the time of survey. The collected samples were air dried, separately bagged and stored under refrigerated condition at $4^{\circ} \mathrm{C}$ for the isolation of the pathogen. The pathogen (M. grisea) of different samples collected during survey was isolated by using the standard tissue isolation method (Tuite, 1969). Blast infected plant tissues were cut into small pieces and washed in sterile water twice and surface sterilized with 0.1 per cent mercuric chloride solution for $30 \mathrm{sec}$. followed by rinsing in sterilized water twice and transferred to plates containing Oat Meal Agar Medium (OMA). After 4 days for obtaining monoconidial isolate, a dilute spore suspension was prepared in sterilized distilled water and plated onto $0.8 \%$ water agar in Petri plates. After 15 days of incubation at $26 \pm 1{ }^{\circ} \mathrm{C}$, single germinating conidium was marked under a microscope and transferred to fresh Petri dish containing OMA medium and then the plates were incubated at $26 \pm 1{ }^{0} \mathrm{C}$ for 10 days to get monoconidial isoloates (Ou, 1985).

\section{Cross-infectivity test}

For cross infectivity test the pathogen from finger millet to foxtail millet (Setaria italica), little millet (Panicum sumatrense), pearl millet (Pennisetum glaucum), rice (Orizea sataiva), kollukattai grass (Pennisetum cenchroides), elephant grass (Pennisetum pureum), dub grass (Cynodon dactylon) and vice versa were tested. Seeds of finger millet (KM 252), foxtail millet var, little millet var, pearl millet var and rice (IR 50) were sown in earthen pots containing potting medium (Red soil- sandFYM at 2:1:1).

The weeds species were collected from field as a clump collected from disease free area in the vicinity of the crop. The pure culture of the blast pathogen from finger millet, foxtail millet, little millet, pearl millet, rice, $P$. cenchroides, $P$. pureum and $C$. dactylon, were isolated and pathogenicity for respective host was confirmed. The cross inoculation from finger millet pathogen to rice and other weeds were done by spraying with the spore suspension from finger millet to other hosts and vice versa. All the inoculated seedlings were kept in glass house at $23 \pm 1{ }^{\circ} \mathrm{C}$ with more than 95 per cent $\mathrm{RH}$ and leaf wetness for $12 \mathrm{hr}$ photoperiod for 10 days. Observation for the presence or absence of disease symptoms was made after 10 days. 
Cross infectivity of leaf blast, neck blast and finger blast within the finger millet

\section{Leaf blast isolates inoculation}

The experiment was carried out in glass house using $30 \mathrm{~cm}$ in diameter earthen pots containing ten seedlings to each pot as described earlier by injecting of spore suspension of $1 \times 10^{5}$ per $\mathrm{ml}^{-1}$ in the top most leaf sheath and observed for symptom appearance by keeping the inoculated pots at $23{ }^{0} \mathrm{C}$ with more than $95 \% \mathrm{RH}$ and leaf wetness for $12 \mathrm{~h}$ photoperiod for 10 days. Three replicates with control were maintained. The observation on presence of neck and finger blast infection was recorded.

\section{Neck and finger blast inoculation}

The isolates of neck and finger blast were inoculated to 15 days old finger millet seedlings separately and labeled by spraying the spore suspension containing $1 \times 10^{5}$ conidia per $\mathrm{ml}$ with $1 \mathrm{ml}$ of teepol. Three replicates with control were maintained. The observation was made for the presence or absence of leaf blast infection.

\section{Result and Discussion}

Testing the cross infectivity of $M$. grisea blast pathogen from different hosts

For cross infectivity test the isolates of $M$. grisea from finger millet was inoculated to other minor millets viz., $P$. sumatrense, $P$. glaucum and S. italica, rice (IR50) and other weed crops viz., $P$. cenchroides, $P$. pureum and $C$. dactylon, and vice versa to find out the host range. The results revealed that the isolates of $M$. grisea from finger millet can infect only weed host viz., $P$. cenchroides, $P$. pureum and $C$. dactylon but not the other minor millets viz., $P$. sumatrense, $P$. glaucum and $S$. italica including rice and vice versa. The cross infectivity test from finger millet leaf blast to infect the neck and finger revealed that the isolates of the leaf blast can cause neck and finger blast infection and the isolates of neck and finger blast can cause leaf infection (Table 1, Plate 1). The results of the present study was in agreement with the work of various workers viz., Ramakrishnan (1948), Kato et al., (1977) and Todman et al., (1994). Todman et al., (1994) reported that the pathogenicity of the blast fungus is largely restricted to its host species of origin, although successful infection of a host by an isolate from a different species has been reported under experimental conditions. Similar results were also obtained by Viji et al., (2000) who found that $M$. grisea isolates from E. coracana failed to infect rice and vice versa. Cross inoculation tests carried out with $M$. grisea isolates from Eleusine and Oryza sativa show that the isolates are host-specific. This result agrees with those of Kato et al., (1977) and Todman et al., (1994), who also found that Magnaporthe isolates from E. coracana failed to infect rice and vice versa. Kumar and Singh (1995) have reported contradictory results regarding the ability of the pathogens from rice and finger millet to cross-infect. The reasons for this variation appear to be the environmental conditions provided during experimentation in addition to the nutritional status of soil (Ou, 1985). Khadka et al., (2012) showed that the $M$. grisea isolates from rice were able to infect all the plant species viz., rice, finger millet, Panicum sp., Eleusine indica and Setaria sp. while isolates from finger millet were only able to infect three plant species viz., E. coracana, Setaria sp. and $E$. indica. In the present study also the cross infectivity was observed within the plant, this was agreed with the earlier work of Smita Puri and Kumar (2012) found that leaf, finger and neck derived $M$. grisea isolates had the ability to cross infect all the three plant parts of Eleusine coracana and could not be separately categorized on their pathogenicity on leaf, neck and panicles. 
Table.1 Cross infectivity of finger millet blast pathogen with different hosts

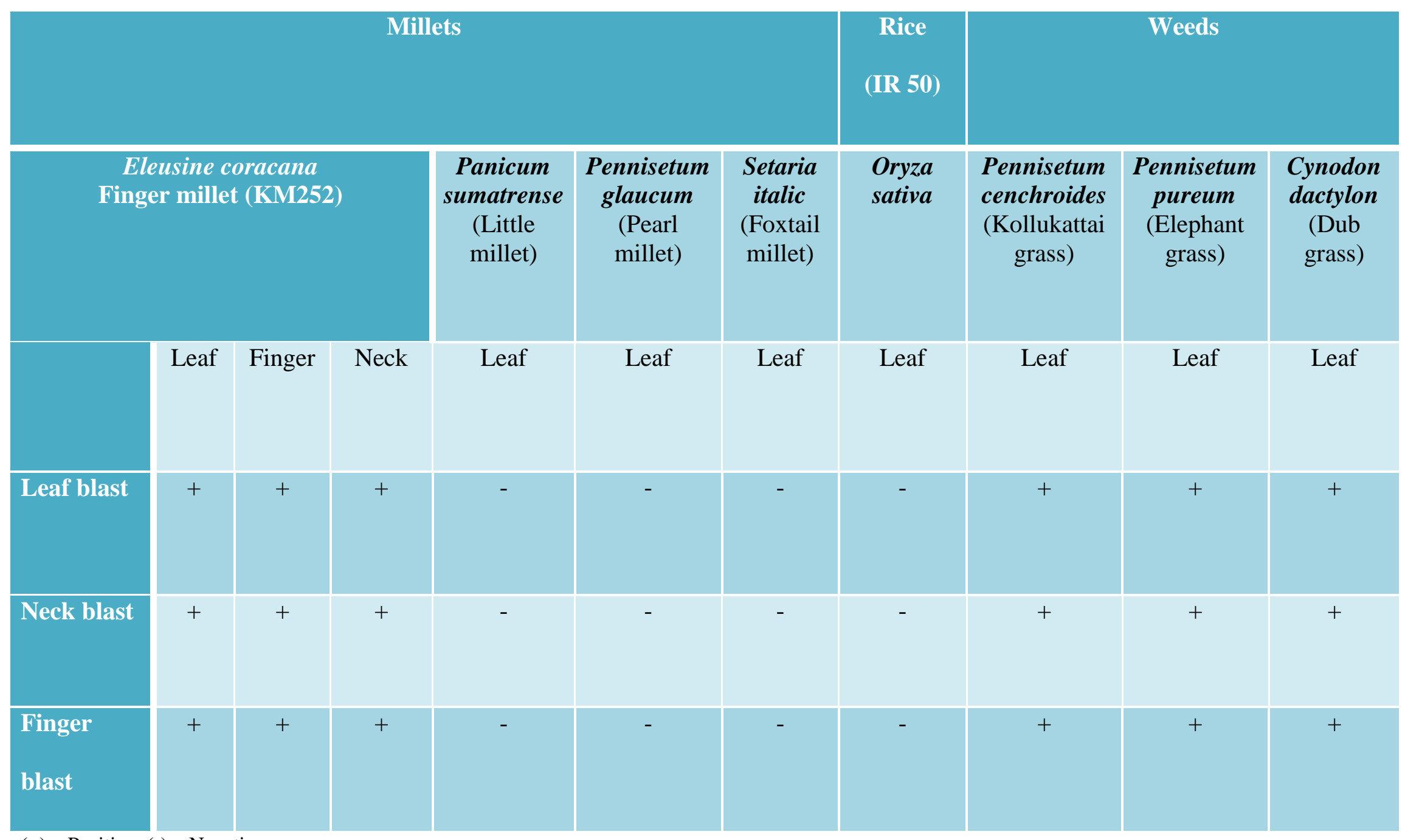

(+) - Positive; (-) - Negative 
Plate.1 Cross infectivity of leaf, neck and finger blast pathogen from finger millet
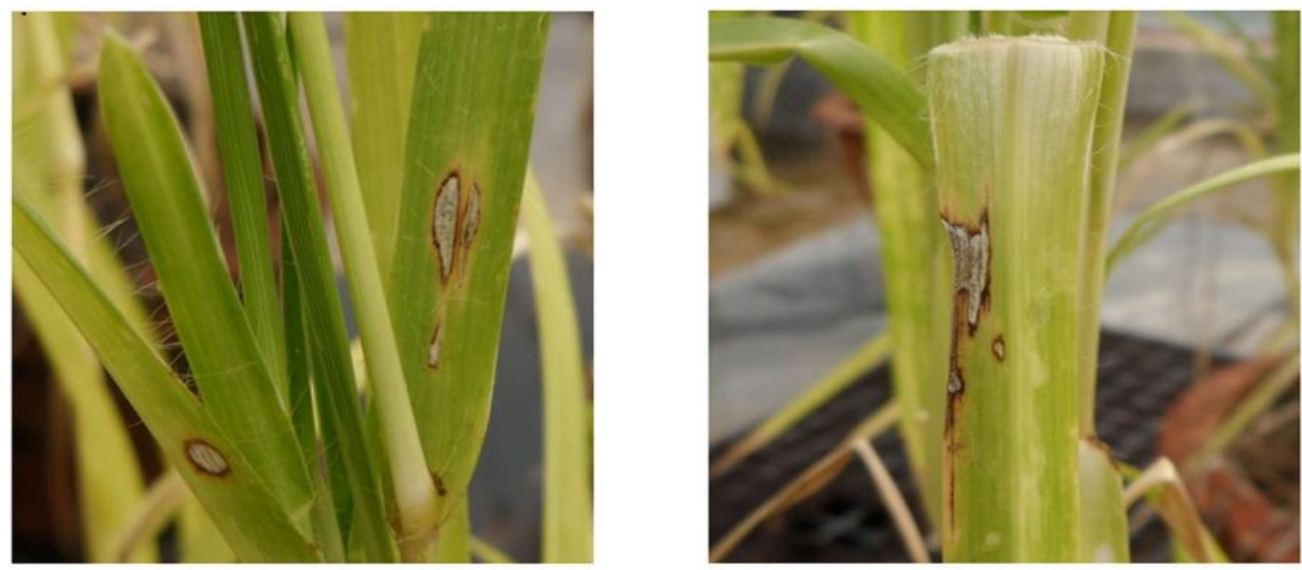

Neck and Finger isolates express symptom on Leaves
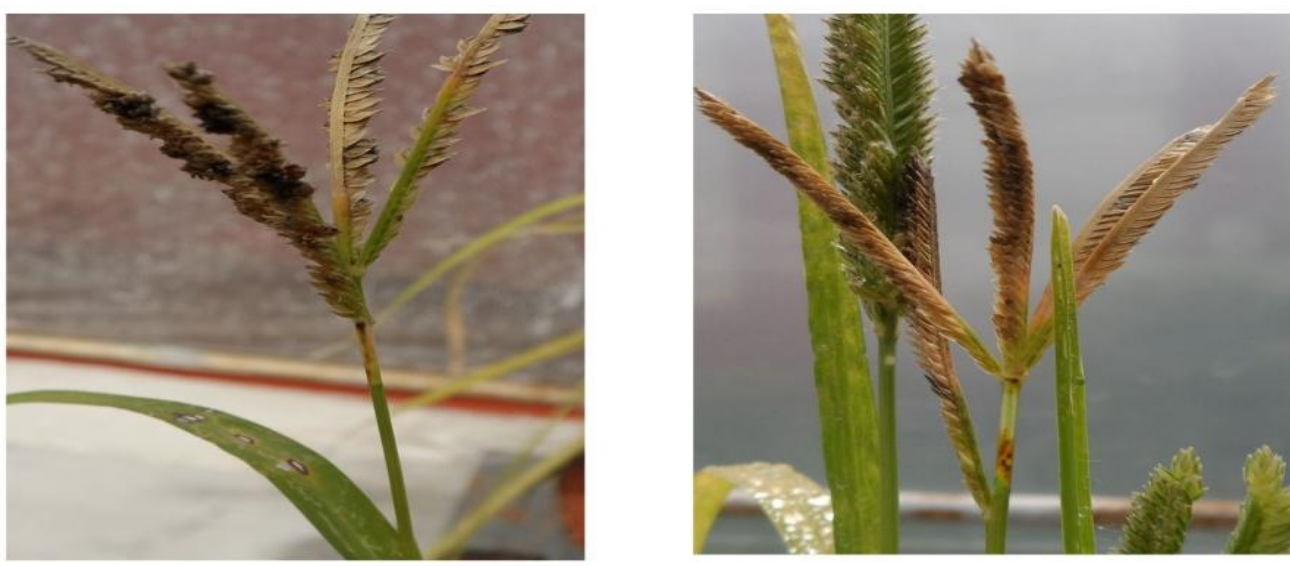

Leaf and Finger isolates express symptom on Neck
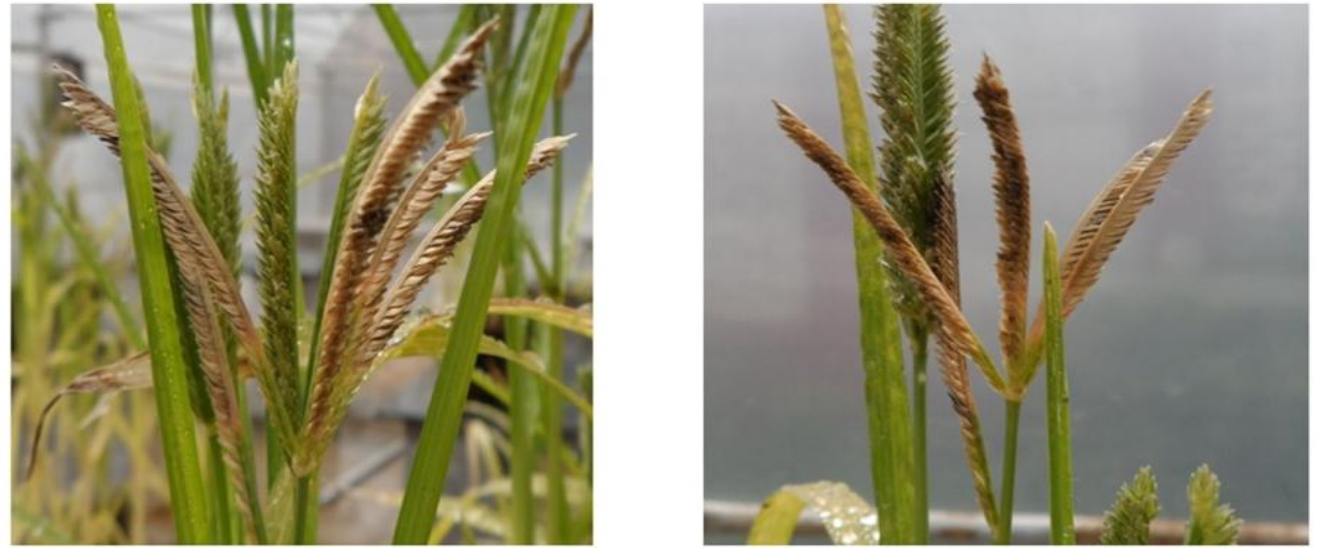

Leaf and Neck isolates express symptom on Finger 
But differing with Silva et al., (2009) who observed low frequency of 15 rare pathotype among panicle blast isolates of rice cv. Bonaca that was not present in the leaf and which may have occurred due to change in the pathotype pattern at adult plant stage before heading and resulted into differential pathogenic behavior.

\section{References}

Kato, H., Yamaguchi, T. and Nishihara, N. 1977. Seed transmission, pathogenicity and control of ragi blast fungus and susceptibility of ragi to Pyricularia spp. from grasses, cereals and mioga. Ann. Phytopath. Soc. Japan, 43(4): 392-401.

Khadka, R.B., Shrestha, S.M., Manandhar, H.K. and Gopal, B.K.C. 2012. Study on differential response of Pyricularia grisea isolates from rice, finger millet and Panicum sp. with local and alien media and their host range. NJST., 13(2): 7-14.

Kumar, A. and Singh, R.A. 1995. Differential response of Pyricularia grisea isolates from rice, finger millet and pearl millet to media, temperature, $\mathrm{pH}$ and light. Indian J. Mycol. Plant Pathol., 25(3): 238-242.

Ou, S. H. 1985. Rice Diseases. Commonwealth Mycological Institute, Kew, Surrey, England.

Ramakrishnan, C.V. 1948. Studies on the morphology, physiology and parasitism of the genus Pyricularia in Madras. Rev. App. Mycol., 46: 668.

Silva, G.B., Prabhu, A.S., Filippi, M.C.C., Trindade, M.G., Araujo, L.G. and Zambolim, L. 2009. Genetic and phenotypic diversity of Magnaporthe oryzae from leaves and panicles of rice in commercial fields in the state of Goias, Brazil. Trop. Plant Pathol., 34: 71-76.

Smita Puri and Kumar, J. 2012. Characterization of leaf, neck and finger blast pathogen populations from Elusine coracana and elucidating their interrelationships in ElusineMagnaporthe pathosystem. Indian Phytopath., 65(2): 133-141.

Thomas, K.M. 1941. Detailed. Adm. Rep. Govt. Mycol., Madras, 1940-41.

Todman, A.K., Pawar, D.R. and Joshi, M.H. 1994. Host reactions to finger millet blast (Pyricularia grisea Sacc.). Mysore J. Agr. Sci., 28: 45-46.

Tuite, J. 1969. Plant pathological methods, fungi and bacteria. Burges Publishing Company, USA, p. 239.

Uddin, W. 2000. Gray leaf spot comes on strong. [Online] available: http://groundsmag. Com/ar/grounds maintenance_gray_leaf_spot/ (09 Oct. 2008).

Viji, G., Gnanamanickam, S.S. and Levy, M. 2000. DNA polymorphism of isolates of Magnaporthe grisea from India that is pathogenic to finger millet and rice. Mycol. Res., 104: 161-167.

\section{How to cite this article:}

Shanmugapackiam, S. and Raguchander, T. 2018. Host Range and Cross Infectivity of the Genus Magnaporthe grisea. Int.J.Curr.Microbiol.App.Sci. 7(08): 3950-3955.

doi: https://doi.org/10.20546/ijcmas.2018.708.407 